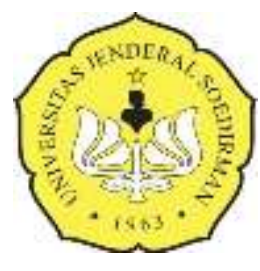

PAJU Volume 1 Nomor 12019

PHYSICAL ACTIVITY JOURNAL

http://jos.unsoed.ac.id/index.php/paju

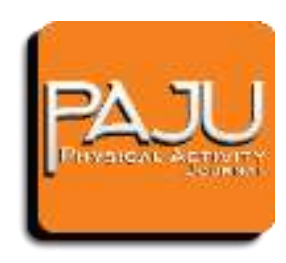

\title{
Fun Water Activity Sebagai Upaya Pencegahan Overweight Pada Anak
}

\author{
Bayu Suko Wahono', Ayu Rizky Febriani², Fuad Noor Heza ${ }^{3}$ \\ 1,2,3 Fakultas IImu-IImu Kesehatan, Universitas Jenderal Soedirman, Indonesia
}

email: bayusukowahono@gmail.com ${ }^{1}$, ayuhidayat13@gmail.com² , fuad.heza@unsoed.ac.id 3 DOI: https://doi.org/10.20884/1.paju.2019.1.1.2003

\begin{abstract}
Abstrak
Maraknya penggunaan game online dalam smartphone pada anak membuat kurangnya aktivitas fisik yang dilakukan sehingga akan menyebabkan penambahan berat badan berlebih atau overweight. Penyebab utama overweight adalah ketidakseimbangan antara energi yang diasup dengan energi yang dikeluarkan dalam tubuh. Anak yang memiliki tubuh overweight akan menimbulkan banyak konsekuensi negatif bagi anak, diantaranya adalah mudah mengalami overweight pada usia dewasa dan lebih rentan terserang berbagai penyakit komplikasi. Salah satu cara yang dapat digunakan untuk mengantisipasi overweight adalah dengan pelaksanaan aktivitas fisik. Fun water activity merupakan salah satu kegiatan bermain dalam air untuk mencegah overweight pada anak dengan aktivitas fisik yang menyenangkan. "Gila Es Putang" merupakan modifikasi permainan menyenangkan dalam air sebagai tindakan pencegahan overweight pada anak yang membuat anak bergerak sehingga kalori dapat terbakar, otot bergerak secara keseluruhan dan menormalkan fungsi jantung serta paru sehingga anak tidak lekas lelah dalam melakukan aktivitas sehari-hari serta mencegah overweight.
\end{abstract}

Kata Kunci : Fun Water Activity, Anak Overweight, Aktivitas Fisik

\begin{abstract}
The rises of online games used on smartphone for children makes a lack of physical activity that will cause excessive weight gain or overweight. The main cause of overweight is imbalance between energy intake and the energy released. Children who are overweight will resulting many negative consequences including more easily overweight in adulthood and more susceptible to dangerous diseases. One alternatif way that can be used to overcome overweight by doing physical activity. Fun water activity is one method to prevent overweight in children with fun physical activities in the water. "Gila Es Putang" is a modification of fun games in the water as preventive measure for overewight in children which makes children move so the calories can burn, overall moving muscles and normalizing heart and lung function so that children can not work in daily activities and also prevent overweight.
\end{abstract}

Keywords: Fun Water Activity, Children Overweight, Physical Activity

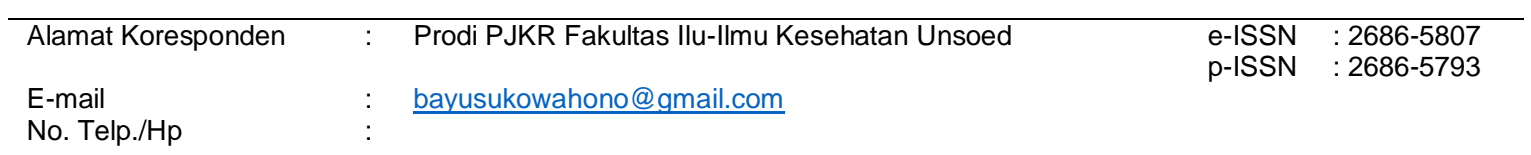




\section{PENDAHULUAN}

Dewasa ini, tidak bisa dipungkiri bahwa perkembangan dan kemajuan ilmu pengetahuan dan teknologi sangat berpengaruh terhadap diri manusia dan lingkungan sekitar. Perkembangan teknologi berupa smartphone ini menjadi pedang bermata 2. Disatu sisi, kehadiaran teknologi smartphone sangat membantu dalam kegiatan komunikasi sehari-hari. Tetapi disisi lain, ada hal besar yang harus dikorbankan yaitu kecenderungan kurangnya mobilitas gerak, tingkat kebugaran jasmani, dan aktivitas fisik penggunanya.

Salah satu teknologi dalam smartphone yang marak digunakan oleh anak-anak pada era ini adalah game online. Game online tidak terbatas pada umur dan jenis kelamin. Mulai dari anak-anak, remaja, dewasa, orang tua, baik itu laki-laki maupun perempuan. Namun, kebanyakan para pemain dari game online ini adalah anak-anak. Anak yang mengalami kecanduan game online dapat menggunakan waktu antara 2 hingga 10 jam per hari (Kusumadewi, 2012) atau rata-rata 20 hingga 25 jam dalam seminggu (Chou, Condron, \& Belland, 2005). Pola asuh orang tua yang memanjakan dan memberikan apa yang diinginkan anak juga merupakan salah satu faktor pemicu kecanduan game online.

Terlebih maraknya permainan game online membuat kurangnya aktivitas fisik secara menyeluruh terutama bagi anak-anak. Kurangnya gerak aktivitas fisik akan menimbulkan kecenderungan overweight pada anak (West, Caterini, Banks, \& Wells, 2018). Secara global, 170 juta anak-anak diseluruh dunia mengalami overweight (World Health Organization, 2012). Overweight pada anak-anak menjadi perhatian World Health Organization (WHO) dengan menetapkan masalah overweight sebagai salah satu indikator untuk mengatasi masalah gizi pada anak-anak melalui Sustainable Development Goals (SDGs). Anak-anak yang mengalami overweight biasanya lebih nyaman untuk beraktivitas didalam rumah daripada aktivitas diluar rumah sehingga lebih nyaman bermain game online dalam smartphone dibandingkan dengan bermain aktivitas fisik dengan teman sebayanya. Jarangnya aktivitas fisik yang dilakukan oleh anak overweight mengakibatkan anak menjadi kurang bugar dan tingkat keterampilan gerak yang kurang, baik gerak lokomotor, non lokomotor, maupun manipulatif (Nurcahyo, 2011).

Tingkat overweight pada anak telah meningkat $2 x$ lipat (dalam beberapa kasus hingga $3 x$ lipat) pada negara berkembang selama 30 tahun terakhir (Cathaoir, 2016). Penyebab utama dari overweight adalah tidak seimbangnya energi yang diasup dari makanan dan energi yang dikeluarkan melalui aktivitas fisik (Williams \& Greene, 2018). Anak-anak yang mengalami overweight akan lebih cenderung mengasup makanan dan nutrisi secara normal tetapi tidak membakar makanan tersebut menjadi energi sehingga mengakibatkan overweight. Namun disisi lain, terdapat berbagai penyebab terjadinya overweight pada anak yaitu nutrisi, kesehatan mental, kualitas tidur dan penggunaan media (Williams \& Greene, 2018).

Memiliki berat badan berlebih atau overweight bagi anak-anak akan kurang baik bagi kesehatan, karena tubuh yang overweight akan mudah terserang penyakit dan tidak bugar. Perlu adanya pengalihan perhatian tehadap kecenderungan bermain game online dalam smartphone. Terdapat banyak cara yang dapat digunakan untuk menstimulasi anak-anak agar dapat lepas dari game online dalam smartphone. Salah satu cara mencegah overweight adalah dengan aktivitas fisik berupa kegiatan bermain yang menyenangkan 
(Febrianta, 2016). Karena pada usia tersebut merupakan masa emas pertumbuhan otak dan fisik, di mana stimulasi, perkembangan kognisi, sosial dan emosi anak mencapai tahap optimal serta tindakan pencegahan lebih baik dilaksanakan daripada mengatasi overweight pada anak (Khodaee \& Saeidi, 2016). Tulisan ini akan membahas tentang aktivitas fisik dalam air yang menyenangkan sebagai upaya mencegah overweight pada anak.

\section{METODE}

Penelitian ini merupakan penelitian kualitatif yang bersifat studi pustaka (library research) yang menggunakan buku-buku dan jurnal sebagai literatur objek yang utama (Hadi, 1995). Penelitian kualitatif merupakan penelitian yang menghasilkan informasi berupa catatan dan data deskriptif yang terdapat dalam bahasan yang diteliti (Mantra, 2008). Studi pustaka merupakan metode yang diarahkan kepada pencarian data dan informasi melalui dokumen-dokumen, baik dokumen tertulis, foto-foto, gambar, maupun dokumen elektronik.

\section{HASIL DAN PEMBAHASAN}

Overweight pada anak merupakan tantangan masalah kesehatan yang serius pada abad ke 21 ini. Overweight merupakan kondisi berat tubuh yang melebihi berat tubuh normal. Anak yang menderita overweight akan memiliki risiko yang tinggi terhadap terjadinya obesitas. Menurut Center for Disease Control and Prevention (CDC), obesitas juga dapat disebut sebagai "extreme overweight". Anak usia dini yang menderita overweight dan obesitas akan lebih rentan untuk menjadi overweight pada usia dewasa (Williams \& Greene, 2018). Kondisi overweight pada anak dapat juga disebut sebagai kondisi endomorph, yaitu kondisi yang menunjukkan gejala fisik berupa gemuk, bulat, dan mudah sakit. Kondisi endomorph ini akan membuat anak gugup, malas dan pelupa. Sementara kondisi ideal pada anak dinamakan mesomorph, yaitu kondisi dimana anak memiliki fisik yang sehat, kuat, dan tangkas yang akan mengakibatkan sikap anak menjadi ramah, sopan, periang dan memiliki banyak teman (Bodley, Papalia, \& Olds, 1979).

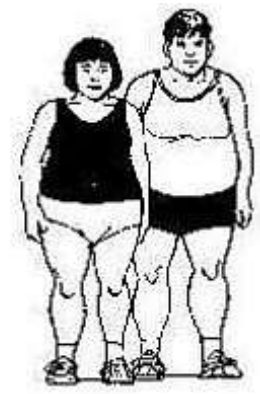

Endomorph

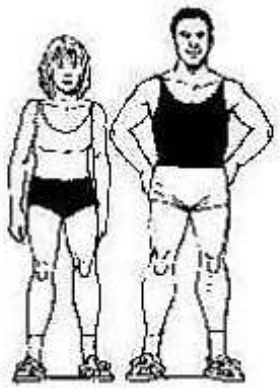

Mesomorph

Gambar 2. Kondisi Endomorph dan Kondisi Mesomorph Manusia

(Bodley et al., 1979) 
Penyebab utama overweight adalah ketidakseimbangan energi yang diasup dari makanan dan energi yang dikeluarkan melalui aktivitas fisik (Williams \& Greene, 2018). Peningkatan konsumsi makanan berkalori tinggi tanpa adanya aktivitas fisik yang seimbang akan menyebabkan peningkatan yang tidak sehat pada berat badan. Di Indonesia, perubahan gaya hidup yang menjurus ke westerinsasi mengakibatkan pola makan masyarakat yang merujuk pada pola makan tinggi kalori, lemak dan kolesterol (Leonita \& Nopriadi, 2010).

Game online dalam smartphone berhubungan terhadap peningkatan berat badan atau overweight dan mengurangi aktivitas fisik pada anak (Goran, Reynolds, \& Lindquist, 1999). Anak yang mengalami overweight akan mudah menjadi overweight pula ketika dewasa dan lebih rentan terserang penyakit seperti dibetes dan masalah pernafasan pada usia muda yang mengarah pada kematian pada usia dini jika dibandingkan dengan anak yang tidak menderita overweight (Khodaee \& Saeidi, 2016).

Aktivitas fisik merupakan salah satu cara yang dapat digunakan untuk mencegah overweight pada anak (Katzmarzyk et al., 2015). Aktivitas fisik didefinisikan sebagai pergerakan baik secara terstruktur maupun tidak terstruktur dalam berbagai kegiatan dengan bermacam intensitas yang mempromosikan kebugaran dan kesehatan yang substansial (West et al., 2018). WHO merekomendasikan aktivitas fisik bagi anak selama 60 menit per hari yang dapat dibagi menjadi beberapa kegiatan (World Health Organization, 2012). Tetapi $38,2 \%$ anak-anak masih belum melakukan aktivitas fisik seperti yang telah direkomendasikan (Katzmarzyk et al., 2015).

Penelitian di negara maju menunjukkan bahwa terdapat hubungan antara aktivitas fisik yang rendah dengan kejadian overweight. Individu dengan aktivitas fisik yang rendah memiliki risiko peningkatan berat badan lebih besar daripada orang yang berolahraga secara teratur. Ada hubungan antara overweight dan aktivitas fisik pada anak-anak, dan ada hubungan positif antara overweight dan kurangnya aktivitas fisik, beberapa mengidikasikan bahwa aktivitas fisik berhubungan positif kepada kegemukan atau overweight (Goran et al., 1999).

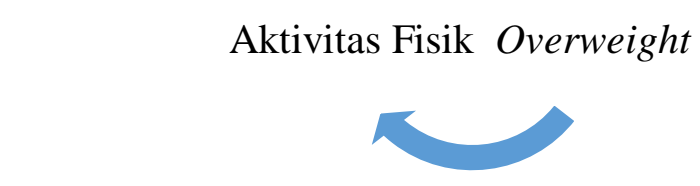

Gambar 2. Ilustrasi Keterkaitan antara Overweight dan Aktivitas Fisik (Nurcahyo, 2011)

Berdasarkan ilustrasi tersebut, rendahnya level aktivitas fisik yang dilakukan oleh anak dapat menimbulkan overweight, dan overweight dapat mengurangi tingkat aktivitas serta kebugaran fisik (Nurcahyo, 2011). Aktivitas fisik sangat penting dilakukan pada saat kanak-kanak karena merupakan pola yang akan membentuk pondasi seumur hidup bagi aktivitas fisik reguler mereka ketika dewasa nanti. Aktivitas fisik juga memberikan keuntungan berupa menjaga berat badan tetap ideal dan dapat berdampak pada perilaku hidup sehat seperti tidak merokok, diet, penggunaan narkoba, aktivitas seksual dan performa 
akademik (Goran et al., 1999). Hubungan tersebut mensugestikan bahwa aktivitas fisik memainkan peran yang penting, tidak hanya dalam ranah pencegahan overweight saja tetapi juga pada berbagai macam konsekuensi kesehatan, gaya hidup, dan perilaku psikologis serta sosial.

Kegiatan fun water activity merupakan kegiatan yang menyenangkan dalam air. Air adalah media yang sangat ideal bagi program latihan dan rehabilitasi, karena ketika berdiri pada kedalaman sebahu maka akan terjadi pengurangan berat badan sebesar $90 \%$ dan juga mengurangi tekanan muskuloskeletal dan persendian (Susanto, 2008). Pelaksanaan aktivitas fisik dalam air diharapkan dapat mengurangi risiko cidera pada anak seperti patah tulang dan dislokasi tulang. Hal ini dikarenakan ketika aktivitas fisik dilaksanakan tidak dalam air, terdapat potensi jatuh yang menyebabkan cidera, sehingga pelaksanakan aktivitas fisik didalam air diharapkan dapat mengurangi risiko cidera tersebut.

Aktivitas fisik berupa olahraga yang dilakukan didalam air dapat menjadi aktivitas untuk membakar kalori. Pembakaran kalori tubuh ternyata tidak selalu ditandai oleh keluarnya keringat. Saat melakukan kegiatan fisik dalam air, tubuh akan terasa lebih berat bergerak sehingga energi yang dibutuhkan menjadi lebih tinggi dan dapat secara efektif membakar sekitar $24 \%$ kalori dalam tubuh. Ketika melakukan aktivitas fisik dalam air, kalori dalam tubuh akan terbakar sehingga secara langsung sangat efektif membakar lemak. Hal ini tentu akan sangat membantu anak-anak yang mengalami overweight.

Fun water activity dapat digunakan sebagai suatu metode perkenalan anak terhadap air, sebelum nantinya akan mempelajari gerak dalam air (renang) secara keseluruhan. Fun water activity merupakan suatu metode yang dapat digunakan untuk membantu anak yang mengalami overweight untuk dapat bergerak melakukan aktivitas fisik. Kegiatan fun water activity dapat membuat anak bergerak sehingga kalori dapat terbakar, otot bergerak secara keseluruhan dan menormalkan fungsi jantung serta paru sehingga anak tidak lekas lelah dalam melakukan aktivitas sehari-hari (Susanto, 2008). Olahraga fun water activity merupakan modifikasi dari kegiatan didalam air yang menyenangkan dengan membuat model kompetisi sehingga anak akan bergerak secara sukarela tanpa harus dipaksa. Gerak atau aktivitas fisik yang disarankan untuk menjaga kebugaran jasmani bagi anak adalah minimal tiga kali dalam satu minggu dengan durasi waktu 60-90 menit dengan intensitas sedang (Irianto, 2000). Melalui aktivitas fisik yang terukur ini, diharapkan dapat membantu menjaga kebugaran jasamani dan membantu penyaluran tenaga serta pembakaran lemak sehingga dapat mencegah terjadinya overweight.

Aktivitas olahraga yang menyenangkan dapat membuat anak bersemangat dalam melaksanakan aktivitas fisik tanpa terbebani dengan kata "olahraga" yang terlihat melelahkan. "Gila Es Putang" atau "Giring Bola Estafet Punggung Tangan" merupakan modifikasi permainan olahraga dalam air dengan sifat menyenangkan bagi anak. Permainan ini dilaksanakan dengan sifat kompetisi antar kelompok yang bertujuan untuk memindahkan bola pingpong dari keranjang start ke keranjang finish dengan menggunakan punggung tangan dan lemparan. Kegiatan ini dapat mempengaruhi koordinasi mata-tangan dimana komponen tersebut merupakan salah satu unsur kondisi fisik yang diperlukan untuk menjadi bugar yaitu melakukan kegiatan tanpa kelelahan (Bompa \& Buzzichelli, 2015). Gila Es Putang dapat mencegah 
overweight pada anak karena anak akan dengan sukarela bergerak melakukan aktivitas kompetisi yang menyenangkan.

"Gila Es Putang" merupakan salah satu modifikasi kegiatan fun water activity yang bertujuan untuk meningkatkan aktivitas fisik anak sehingga akan mengurangi risiko overweight pada anak. Gila Es Putang atau Giring Bola Estafet Punggung Tangan merupakan salah satu kegiatan bermain dalam air yang menyenangkan yang dapat membuat anak secara sukarela melakukan aktivitas fisik tanpa ada paksanaan. Hal ini dikarenakan Gila Es Putang merupakan permainan kompetisi sehingga terasa asik untuk dimainkan. Fun water activity Gila Es Putang merupakan permainan menyenangkan didalam air yang bertujuan untuk memindahkan bola pingpong dari keranjang ditempat start dengan punggung tangan secara berkelompok ketempat keranjang finish.

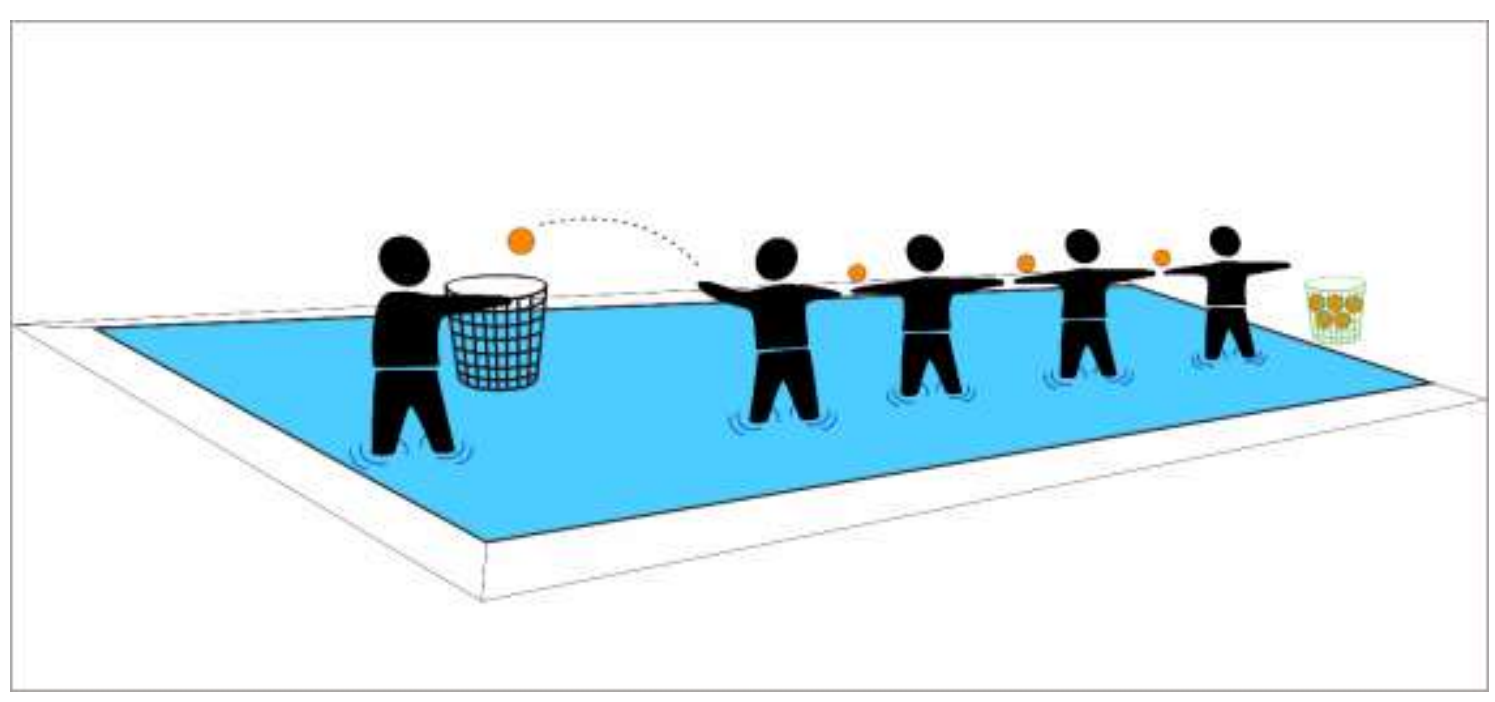

Gambar 3. Tata Cara Pelaksanaan Modifikasi Fun Water Activity "Gila Es Putang"

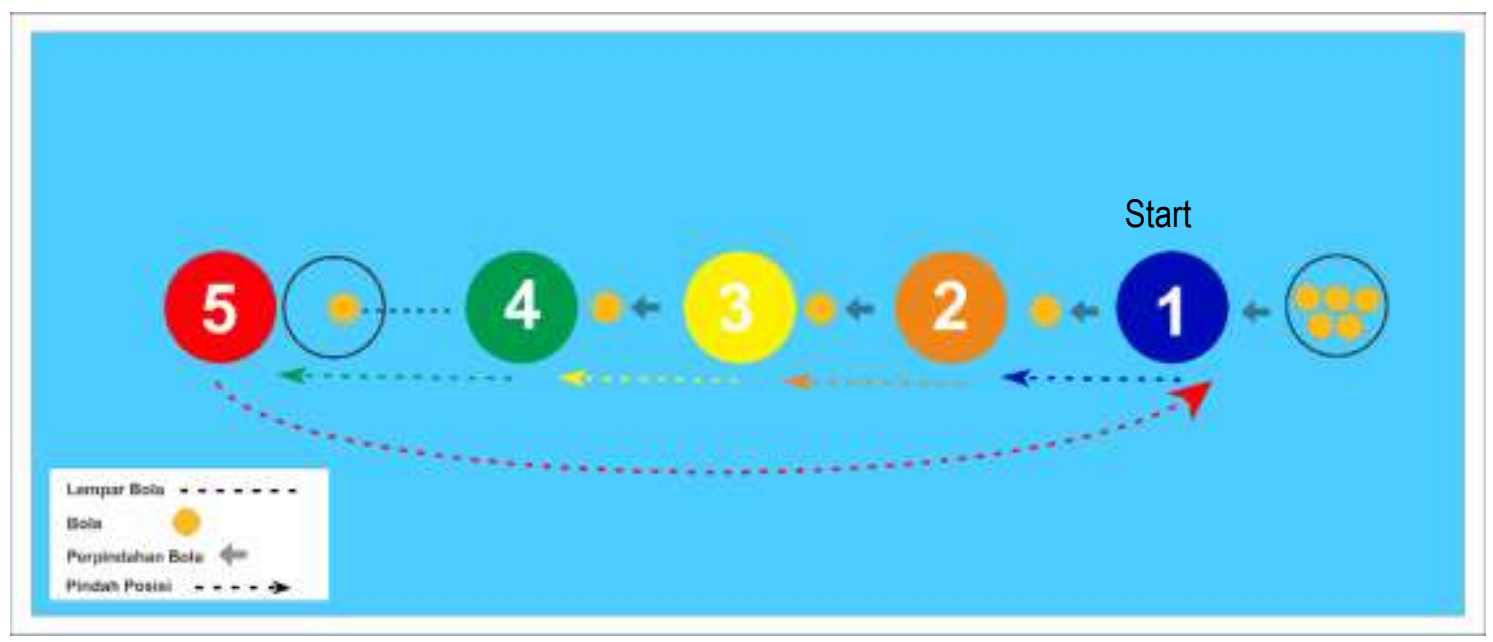

Gambar 4. Lintasan Modifikasi Fun Water Activity "Gila Es Putang"

Tata cara pelaksanaan Modifikasi Fun Water Activity Gila Es Putang:

1. Permainan dimulai dengan peserta berbaris berbanjar didalam kolam berisi air setinggi pinggul atau lutut

2. Pemain paling kiri mengambil bola pingpong dengan punggung tangan kiri lalu menyatukan kedua tangan didepan dada dan memindahkannya ke punggung tangan kanan 
3. Pemain pertama kemudian memindahkan bola pingpong dari punggung tangan kanannya ke punggung tangan kiri peserta kedua

4. Kemudian permainan dilanjutkan ke peserta kedua hingga peserta keempat

5. Dilanjutkan peserta terakhir yang membawa bola pingpong untuk diserahkan ke rekan yang telah menunggu dengan membawa keranjang dengan jarak yang bervariasi (1-3-5-7-9 meter) tergantung tingkat kesulitan yang dihendaki

6. Apabila pada fase penyerahan sudah dilaksanakan, keranjang diberikan kepada peserta terakhir yang memberikan bola (peserta keempat), lalu peserta terakhir yang menerima bola (peserta kelima) berlari ke barisan paling belakang untuk melanjutkan aksi mengambil bola pingpong kemudian dioperkan kembali keperserta selanjutnya

7. Permainan dinyatakan berhenti apabila semua pemain sudah kembali ketempat semula seperti saat permainan dimulai

8. Permainan ini dapat dilaksanakan dua kelompok sehingga dapat dijadikan kompetisi

9. Pemenang dihitung berdasarkan banyaknya bola pingpong dikeranjang dalam waktu tercepat

10. Pemain sejumlah 5 orang dan bola pingpong 6 buah (atau dapat bervariasi)

\section{SIMPULAN}

Penelitian yang dilakukan pada 20 negara didunia menunjukkan hasil bahwa dengan dilaksanakannya aktivitas fisik pada anak akan dapat mencegah overweight (Pinto et al., 2018). Kejadian overweight pada anak dapat dicegah dengan pelaksanaan aktivitas fisik yang ringan secara terus menerus (Tristiyanti, Tamtomo, \& Dewi, 2018). Salah satu aktivitas fisik yang dapat dilaksanakan adalah kegiatan fun water activity berupa permainan Gila Es Putang. Aktivitas bermain yang menyenangkan tersebut dapat mencegah overweight pada anak. Berdasarkan rekomendasi spesifik, pencegahan overweight pada anak dapat dilakukan dengan kombinasi nutrisi yang tepat, kualitas istirahat yang baik, penggunaan media yang tidak berlebihan, serta yang tidak kalah penting adalah pelaksanaan aktivitas fisik terutama aktivitas fisik yang menyenangkan bagi anak (Williams \& Greene, 2018). Keterbatasan dalam artikel ini adalah hanya membahas salah satu aktivitas fisik yang berhubungan dengan koordinasi mata tangan saja. Bagi penelitian selanjutnya dapat memasukkan komponen kecepatan, daya tahan meliputi kinerja otot, jantung dan paru, serta koordinasi gerak.

\section{REFERENSI}

Bodley, M. J., Papalia, D. E., \& Olds, S. W. (1979). A Child's World, Infancy Through Adolescence. The Family Coordinator. https://doi.org/10.2307/583294

Bompa, T., \& Buzzichelli, C. (2015). Periodization Training for Sports (Third Edition). United States: Human Kinetics.

Cathaoir, K. (2016). Childhood obesity and the right to health. Health and Human Rights, 18(1). 
Center for Disease Control and Prevention (CDC). 2000.

Chou, C., Condron, L., \& Belland, J. C. (2005). A review of the research on Internet addiction. Educational Psychology Review. https://doi.org/10.1007/s10648-005-8138-1

Febrianta, Y. (2016). Alternatif Mengembangkan Kemampuan Motorik Kasar Anak Usia Dini Dengan Aktivitas Akuatik (Berenang). Al Athfal: Jurnal Pendidikan Anak, 2(2).

Goran, M. I., Reynolds, K. D., \& Lindquist, C. H. (1999). Role of physical activity in the prevention of obesity in children. International Journal of Obesity. https://doi.org/10.1038/sj.ijo.0800880

Hadi, S. (1995). Statistik II. Jakarta: PT. Rineka Cipta.

Irianto, D. P. (2000). Panduan Latihan Kebugaran yang Efektif dan Aman. Yogyakarta: Lukman Offset.

Katzmarzyk, P. T., Barreira, T. V., Broyles, S. T., Champagne, C. M., Chaput, J. P., Fogelholm, M., ... Church, T. S. (2015). Physical Activity, Sedentary Time, and Obesity in an International Sample of Children. Medicine and Science in Sports and Exercise. https://doi.org/10.1249/MSS.0000000000000649

Khodaee, G. H., \& Saeidi, M. (2016). Increases of obesity and overweight in children: An alarm for parents and policymakers. International Journal of Pediatrics, 4(4). https://doi.org/10.22038/ijp.2016.6677

Kusumadewi, T. (2012). Hubungan antara Kecanduan Internet Game Online dan Keterampilan Sosial pada Remaja. Jurnal Psikologi Universitas Indonesia.

Leonita, E., \& Nopriadi, N. (2010). Persepsi Ibu Terhadap Obesitas pada Anak Sekolah Dasar. Jurnal Kesehatan Komunitas, 1(1). https://doi.org/10.25311/jkk.vol1.iss1.9

Mantra, I. B. (2008). Demografi Umum. Yogyakarta: Pustaka Pelajar.

Nurcahyo, F. (2011). Kaitan antara Obesitas dan Aktivitas Fisik. Medikora, 7(1).

Pinto, R., Silva, J., Monteiro, G., De Resende, R., Clemente, R., \& De Souza, C. (2018). Physical Activity: Benefits for Prevention and Treatment of Childhood Obesity. Journal of Childhood Obesity, 3(5). https://doi.org/10.21767/2572-5394.100058

Susanto, E. (2008). Olahraga Renang Sebagai Hidrotherapy Dalam Mengatasi Masalah-Masalah Kesehatan. Medikora, IV(2).

Tristiyanti, W. F., Tamtomo, D. G., \& Dewi, Y. L. R. (2018). Analisis Durasi Tidur, Asupan Makanan, dan Aktivitas Fisik sebagai Faktor Risiko Kejadian Obesitas pada Balita Usia 3-5 Tahun. Sari Pediatri, 20(3). https://doi.org/10.14238/sp20.3.2018.178-84

West, S. L., Caterini, J., Banks, L., \& Wells, G. D. (2018). The epidemic of obesity and poor physical activity participation: Will we ever see a change? Journal of Functional Morphology and Kinesiology. https://doi.org/10.3390/jfmk3020034

Williams, S., \& Greene, J. (2018). Childhood Overweight and Obesity: Affecting Factors, Education and Intervention. Journal of Childhood Obesity, 3(2). https://doi.org/10.21767/2572-5394.100049

World Health Organization. (2012). Population-Based Approaches to Childhood Obesity Prevention. Switzerland: WHO Press. 